\title{
O Desenho Cultural da Arquitetura Guarani
}

\author{
Carlos Zibel Costa
}

\begin{abstract}
Aborda-se a habitação dos indígenas guarani-mbya, estabelecendo alguns compromissos culturais, especialmente aqueles descobertos nas tradiçōes rituais e mitológicas.

O artigo procura dar alguns desdobramentos à característica cultural guarani. segundo a qual sua tradição ou modo de ser - teco - só pode se realizar dentro de uma espacialidade particular, no seu tecoa - 'lugar onde vivemos segundo nossos costumes' (Meliá, 1988:104).
\end{abstract} \footnotetext{
This work is about the guarani-mbya tribe dwelling, and its relation to their cultural characteristics, especially those found in the ritual and mythological traditions. The guarani-mbyá way of life or tradition - teco - can just exist in their own place - tecoa - which means 'place where we live according to our own way of life' (Meliá, 1988:104).
}

Artigo elaborado com base na Tese de Doutorado "Habitação Guarani, tradição construtiva e mitologia", apresentada em dezembro de 1989. Orientadora: Prof Dra Marlene Picarelli 


\section{Introdução}

Procura-se demonstrar a profunda ligação de algumas tradições culturais da parcialidade indigena guarani-mbyá (que junto aos guaranis das parcialidades nhandeva e caiová compōem a presença atual deste grupo em solo brasileiro), com o desenho da sua Arquitetura. Esta pesquisa vem sendo realizada nas aldeias da Barragem e Jaraguá em São Paulo e Aguapeú em Mongaguá desde o ano de 1985. Neste texto, o termo desenho irá se referir tanto ao conceito para o qual ele é desígnio - logo, intençāo, quanto ao sentido convencional de traço - sintese gráfica ou visual de um programa arquitetônico e discurso técnico sobre a construção do espaço. É preferivel criar a expressāo 'desenho cultural' a empregar o termo 'culturalístico' que traria compromissos diversos daqueles pretendidos neste trabalho.

Remete-se o leitor interessado nos detalhes da pesquisa que originou as idéias expostas abaixo, à tese de doutorado do autor e, como se expõe também desenvolvimentos posteriores das idéias contidas na tese, às indicações bibliográficas ao final deste texto. Lembra-se ainda que os étimos em guarani, mesmo que näo acentuados, são invariavelmente oxítonos.

Nesta oportunidade abordam-se partes dos mitos de Origem da Humanidade Guarani, de Fundação da Primeira e da Segunda Terra e o complexo cultural denominado Busca da Terra sem Mal em aspectos que têm ligação direta com o conceito guarani de espacialidade, tecoa - lugar onde se pode realizar a cultura guarani - teco. Vale lembrar que numa cultura tradicional as informações podem adquirir e de fato normalmente adquirem, várias formas de expressão. Os mitos são encontrados em versões aparentemente distintas, mantendo porém correspondência de significado. Sabe-se que vários estudiosos demonstraram que a essência do mito permanece pela sua estrutura em todas as versōes.

Ver-se-á como algumas idéias contidas nesses mitos e tradiçōes se revelam na intençāo da Arquitetura guarani e mesmo no seu desenho. Trata-se mais de observaçōes documentadas, do que de análise exaustiva dessas presenças, o que foi feito na tese com estas e outras idéias, e poderá ser convenientemente aferido na bibliografia indicada. O objetivo do trabalho é estabelecer de modo direto e por vezes abrupto, em decorrência da limitação natural de um artigo. algumas conexões suficientes para demonstrar o caráter intelectual da arquitetura tradicional guarani. Pretende-se ainda que este artigo sirva para lembrar que algumas raízes tecnológicas e culturais da arquitetura vernacular brasileira de origem cabocla, como aquela dos caipiras e caiçaras, se apóia diretamente na cultura tupi-guarani.

\section{Tradições Culturais}

Como em todas as culturas tradicionais, também entre os guarani-mbyá o mito e o ritual embasam seu conhecimento (Schaden, 1974 e Foster, 1962). Para se compreender de modo operacional as motivaçōes e os procedimentos ligados às soluções e às técnicas da arquitetura guarani, dever-se-ia considerar as informações (Nimuendajú, 1987; Cadogan, 1959 e Ladeira, 1992) contidas nos mitos e nas demais tradições com a mesma firmeza da comunidade indígena. Os mitos mais importantes neste caso são os mitos de Origem e Fundação e a tradição da Busca da Terra sem Mal - Yvy Marãe'y; esta busca deu origem a migraçōes passadas e recentes que estabeleceram a atual rede de aldeias 
que, neste sentido, é testemunha dos itinerários e das características que se apresentaram durante a marcha.

Diz-se que este mundo é a segunda terra - Yvy Apy - terra imperfeita e que a primeira - Yvy Tenondé - teve sua humanidade destruída por um dilúvio. Aguarda-se ainda a destruição desta por intermédio do fogo. Para fugir do destino certo, o guarani deve retornar ao seu lugar de origem, no 'Paraíso' Yvy marãe'y, ainda em vida, com seu corpo e sua alma transportados magicamente pelo assento ritual - apica. Para tanto, ele conta com, no mínimo, duas tradiçōes ainda em plena vigência: a busca de um lugar próprio onde sua alma tem as melhores possibilidades de realização - aguyje - e as técnicas de pajelança, através de procedimentos tais como jejuns, cantos, rezas e danças religiosas. Observa-se que aquelas são manifestaçōes normalmente interligadas: a procura do lugar proprio pressupōe o exercício de técnicas de pajelança enquanto a técnica de pajelança só poderá se realizar inteiramente quando o praticante estiver no seu lugar - tecoa - próprio. Ressalte-se que apesar do aguyje ser fruto de conquista individual, ele como valor máximo a ser alcançado dentro da cultura guarani, implica que o conjunto de procedimentos para obtê-lo seja de atividades comunitárias que Meliá (1990:45) denomina economia de reciprocidade.

A busca do lugar ideal se apóia, por seu lado, em duas outras tradiçōes:

1 - No repovoamento da segunda terra. Nhamandu Ete, a Divindade. enviou nomes/almas - ayvu - à terra, em locaıs na sua extremidade. sua fundação, ou seja, no litoral. O retorno da alma guaranı deve portanto seguır direção leste (Oceano Atlântico), no sentido anti-horário.

2 - Como cada pessoa recebe a alma divina através de uma das cinco divindades, esta pessoa pode receber dela. através da alma enquanto canal, outras informaçōes como por exemplo, qual o local definitivo da sua morada - Tecoa. Esta comunicação é feita em sonhos ou durante a concentração das rezas na opy - casa de rezas. Nesta cultura o líder acumula as funções política e religiosa, embora seja, como comportamento e caráter, mais claramente um líder espiritual. As mulheres participam ativamente das funções de liderança junto ao seu grupo familiar, inclusive nas cerimônias religiosas e na função essencial de sonhar com o lugar definitivo de moradia da sua família, já que o homem somente dirige e nāo sonha (Cadogan. 1950 e Ladeıra, 1992).

\section{O Desenho da Arquitetura}

Na procura da Terra sem Mal, os guaranis foram ocupando esparsamente a faixa Rio Grande do Sul/Espírito Santo, desde o interior do Paraguai até o litoral brasileiro (Fig. 1).

Tal ocupação, como demonstrado por Hélène Clastres (1978), foi ocasionada mais pela motivaçāo religiosa do que por razões políticas ou sociais. Assim, os assentamentos guaranis percorrem rotas tradicionais e apóiam-se em uma geografia mítica' bem determinada, ainda que sem o recurso, dispensável, da cartografia (Ladeira e Costa, 1992).

Diz-se que na primeira terra, que era plana. o suporte eram dois paus cruzados. ou hastes de milho; essa terra foi transformada pela retirada de um esteio. que ocasionou terremoto e conseqüentemente os acidentes geográficos; nessa época surgiram os primeiros guaranis. O dilúvio subseqüente nāo alterou nada dessa topografia e segundo algumas versōes, veio para purificar a 
Fig. 1

Ocupação tupi-guarani do Brasil (IBGE, 1987); mapa etno-histórico (apud Nimuendajú, 1944).

Fonte: IBGE (1987)

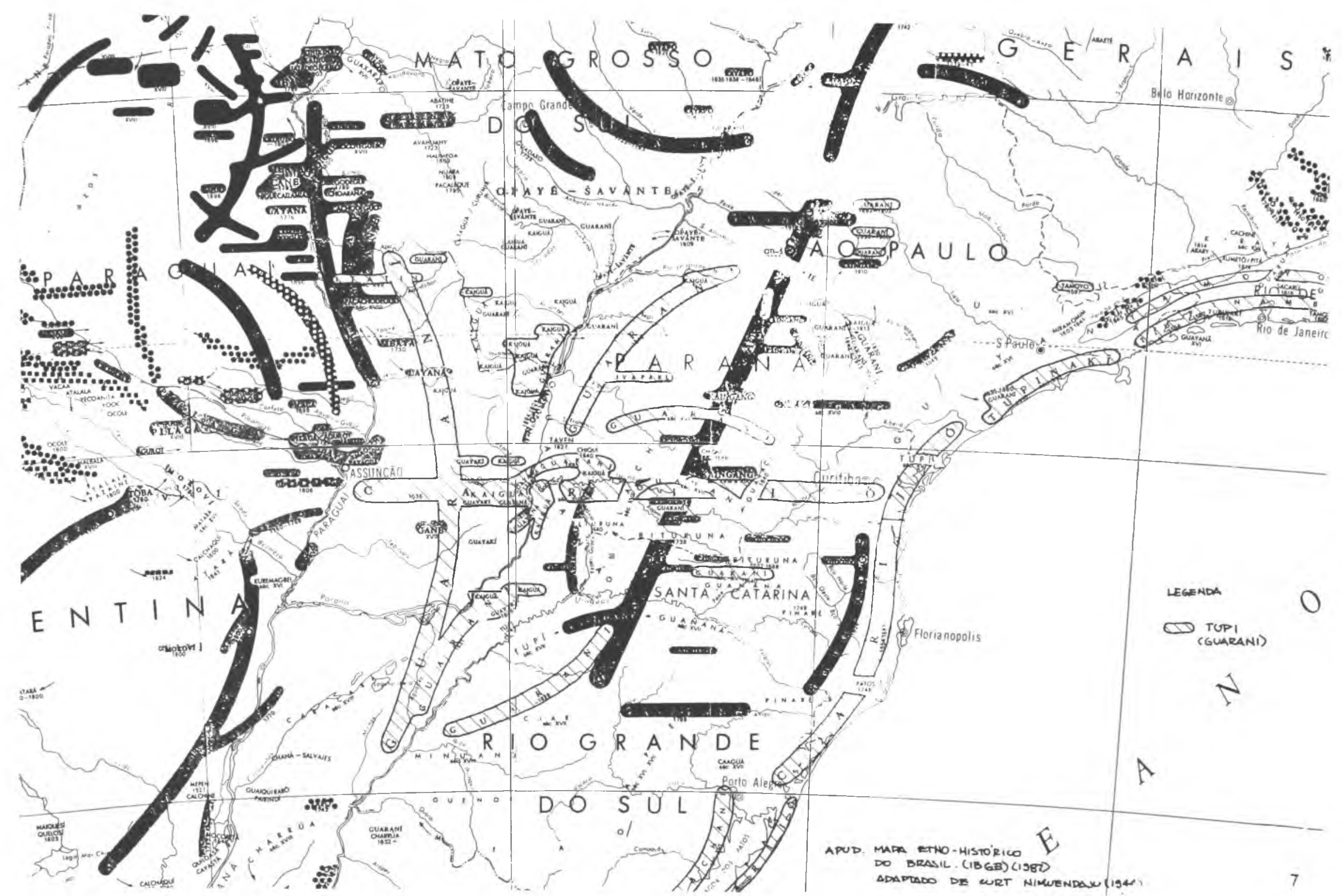

Foto 1

Açude construído pela comunidade em nascente de água localizada no extremo sul do terreno. Notar a face oriental desempedida.

Foto: Carlos Zibel Costa

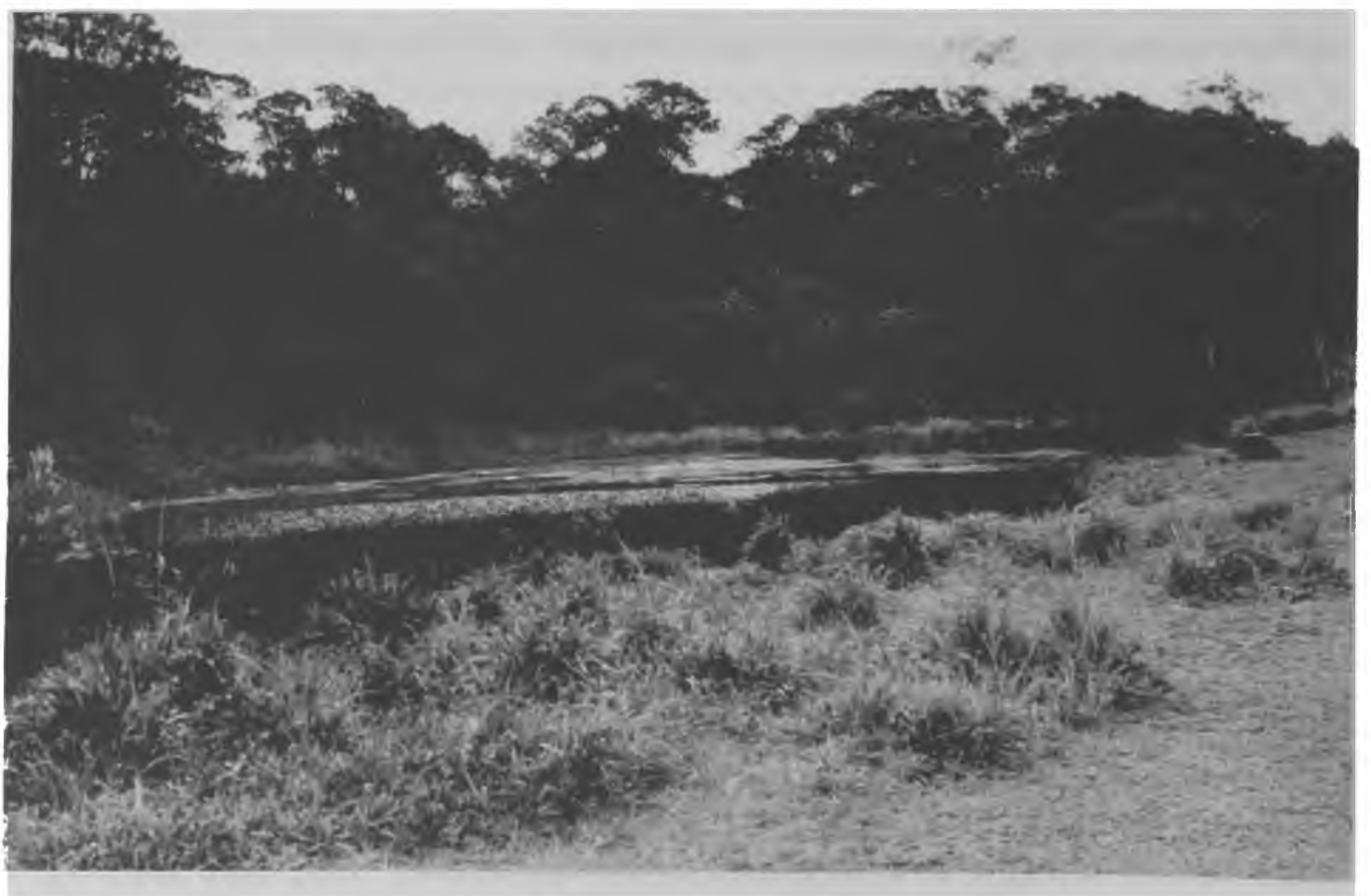


humanidade. A segunda terra tem fundamentos - rapyta - de pedra - ita - que não se acabam, como foi o caso dos fundamentos anteriores de madeira. A destruiçāo dessa segunda terra será, assim, pelo fogo.

Certas configurações líticas naturais como penhascos, ou mesmo as ruínas de pedra das Missões, são lembradas como marcas da divindade e locais da extremidade e fundaçāo - rapyta - da terra. O mito de fundação do mundo diz que foram criados esteios terrestres - rapyta - de palmeira; a palmeira - pindo - intensamente usada, aliás, como estrutura da construção, que também se chama ita, passa a ter assim, função semântica similar à pedra enquanto material construtivo.

Outras marcas topológicas no sítio pretendido são a presença de uma nascente de água voltada para o sol (N-E-W) e da palmeira - pindo. No mito da Nossa Avó Primeira é dito que onde ela morava havia fonte de agua ao pé de uma palmeira onde vinham se abrigar alguns anımais: diz-se ainda que as marcas de sua presença ficaram gravadas em pedra nos locais por onde ela andou. sendo até hoje acessivel para os verdadeiros guaranis.

Como o mito relata que a fonte de água era banhada pelos raios de sol, essa peculiaridade esclarece que a fonte tinha face oriental (Foto 1). Este mito ensina ainda que, biunivocamente, os guaranis devem procurar tais marcas para recuperar os locais de presença da divindade, ou seja, locais na extremidade - fundação - do mundo de onde a humanidade veio do céu e que isto só será possivel para aqueles que preservem suas tradiçōes.

Quanto a essa última condição, sabe-se que a migração empreendida, por ser ritualística, compreende sem dúvida o cumprimento das tradiçōes; por outro lado, como o litoral é considerado um extremo do mundo. ou seja, lugar de fundamento, identifica-se com o conceito de rapyta. Viu-se que também pedras estão associadas ao esteio e fundação - ita - e com maior razão, acidentes geográficos compostos por pedras, como penhascos e as próprias serras yvyty. Assim, pode-se afirmar que nos locais pretendidos devem existir palmeiras, fonte de água voltada para o sol, animais e vegetais relatados nos mitos, pedras e acidentes geográficos como marcos do território, o que denota local possuidor de atributos do fundamento do mundo.

Estudos de campo, bem como pesquisas recentes. fruto de síntese bibliográfica e investigação arqueológica, concordam em que o padrāo do estabelecimento guarani subentende ocupações em "elevação de pouca altura, em áreas de vegetaçāo florestal" dentro de habitat "sem estação seca ... localizados em suaves elevaçōes na proximidade do mar, próximo a pequenos riachos ou aos grandes rios dos vales costeiros" (Scatamacchia e Moscoso. 1989). Aldeias do litoral paulista, como a de Aguapeú em Mongaguá, encarnam perfeitamente o padrão citado. mesmo porque implantadas nas fraldas suaves de morros, voltam-se para o norte e oriente, sempre face ao mar e próximas de rio ou nascente de água.

Numa das versōes do mito do dilúvio (Cadogan, 1959) é dito que quando as águas vieram, os guaranis que rezavam atingiram a perfeição religiosa e social - aguyje - e salvaram-se montados no seu banquinho ritual; entretanto, um casal incestuoso. tia e sobrinho, tiveram que nadar por três meses, rezando. até que lhes adveio o fervor verdadeiro - aguyje - e surgiu uma Pindovy palmeira verde/azul, eterna - na qual se abrigaram em duas folhas até irem para o céu dos deuses menores. Em outra versão (Nimuendajú. 1987), os guaranis estavam em sua casa de rezas, que ficava no alto da Serra de Paranapiacaba e, quando viram que as águas chegavam, eles rezaram e a 
casa de rezas - opy - com todos os seus componentes, subiu para a Terra sem Mal - Yvy marãe'y.

O primeiro mito indica a centralidade da palmeira como espécime vegetal e local adequado à realização da perfeição social e espiritual e explica que a palmeira pode corresponder de algum modo à casa de rezas enquanto local dos ritos guaranis. Considerando que o casal incestuoso atinge o céu dos deuses menores a partir da palmeira eterna - pindovy - usando o banquinho ritual e que no caso da outra versão a casa de rezas é o próprio instrumento que leva toda a família, inclusive objetos e animais domésticos diretamente para o céu, as duas versões míticas indicam que a casa de rezas comporta, além de uma certa equivalência com a palmeira pindovy e com o banco ritual, apica, dois conceitos funcionais: local adequado e veículo do aguyje.

Outras tradiçōes referem-se às características físicas de certas árvores. O cedro era usado como madeira estrutural para a habitação; hoje restringe-se, pela sua raridade, ao uso na casa de rezas e mesmo assim em partes dela, especialmente nos objetos rituais como o bastão de reza masculino - yvyra'ino banquinho e no altar. A explicação que se obtém para a preferência pelo cedro - ygary - é que se trata de uma madeira boa e forte para a construção assim como, os guarani afirmam, todas as madeiras duras são adequadas. Porém, uma análise mais cuidadosa das suas tradiçōes esclarece que o cedro está classificado entre as madeiras sagradas, assim como pindo-palmeira, yvyraovi, kurupika'y, gwapo'y, aju'y, etc.; todas elas também utilizadas na produção de fogo (Cadogan, 1959).

O cedro é madeira excelente para uso naval e a própria designação de canoa - ygara - parece ter etimologia em ygary, cedro; além disso, o altar de reza da

Folo 2

Interior da opy principal do cacique José Fernandes. Notar bastão de reza masculino, colares e maracá pendurados no altar - yvira'i. Atrás, parede leste: notar violão (usado nas rezas como mbaraca - percussāo) e taquara - tacuaçu - usado ritualmente pelas mulheres.

Foto: Candida Maria Vuolo (LRAV-FAUUSP)

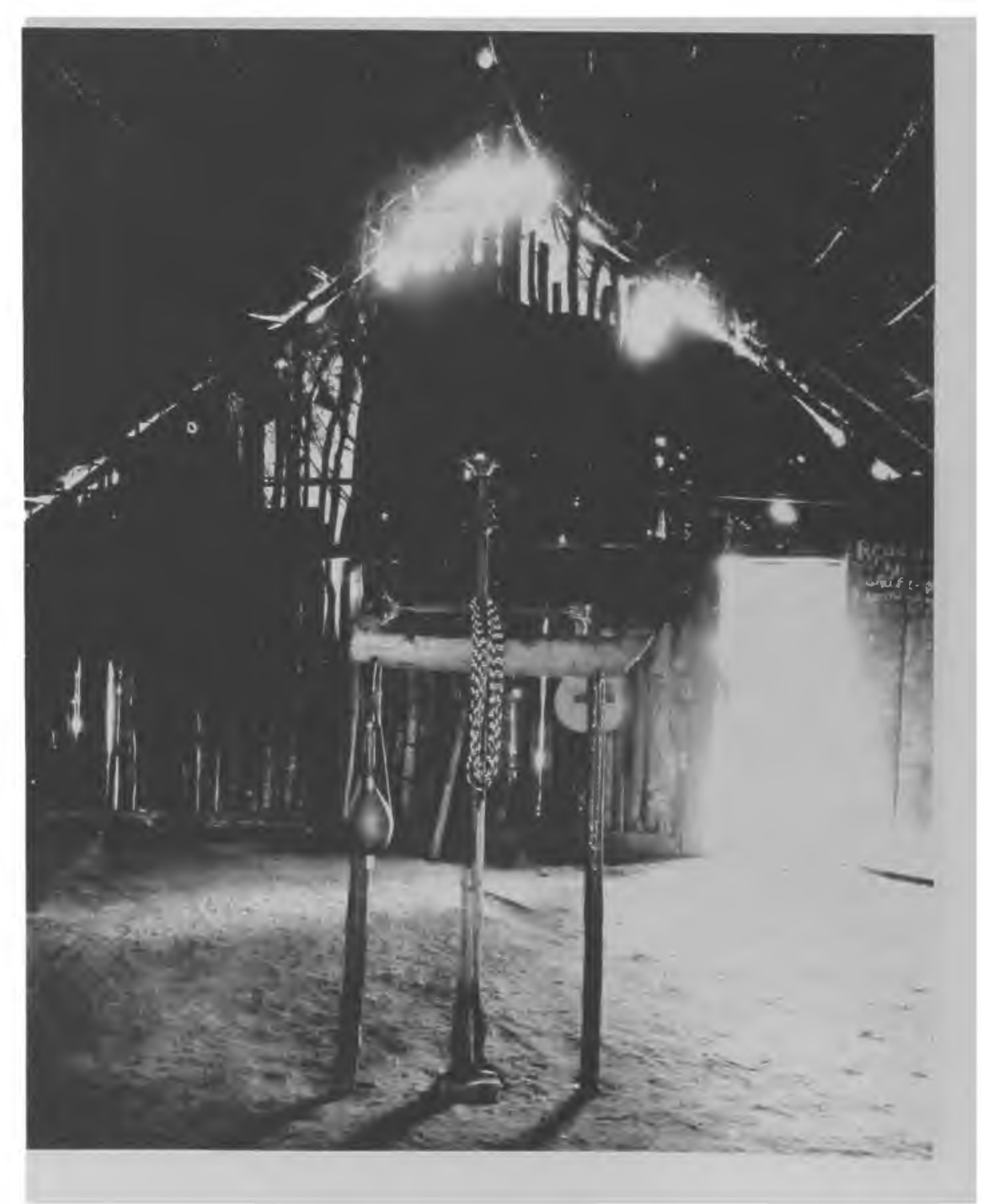

Pós - R. Prog. Pós-Grad. Arquit. Urb. FaUUSP. Sáo Paulo n.4 p. 113-130 dez. 1993 
aldeia da Barragem, em São Paulo, feito todo em cedro, apresenta uma composiçāo em pórtico onde o travessão parece representar uma pequena barca. Se lembrarmos que as rezas estão referidas direta ou indiretamente à Terra sem Mal, destino final das suas migrações enquanto local da perfeição e que, este local situa-se além do mar ou no próprio centro do mar sendo atingido pelo transporte sobre as águas no banco ritual, apica - que tem forma de canoa - estas características podem ganhar outra dimensāo e obtem-se uma grande coerência semântica e pragmática (Foto 2).

Além disso, o cedro e as outras essencias arbóreas sagradas são designadas como yvyra nhe'ery - árvores do orvalho ou da palavra (Cadogan, 1971). Quer dizer, árvores sagradas, pois gotejam seiva, gotas de orvalho, em épocas determinadas. Deve-se lembrar que esta seiva, sendo associada ao orvalho, passa a ter a natureza curadora e regeneradora deste que é uma das manifestações da divindade Jacaira/Jesuca. extremamente benefıca para os guaranis. Essa divindade se manifesta no mundo natural. além do orvalho e da seiva, através da neblina vivificante - tataxina - que inunda as terras guarani e corresponde no mundo da cultura à fumaça do cachimbo - petingua - que é usado como elemento indispensável em todo ritual, instrumento de cura e meditação e veículo das belas palavras do pajé.

De todas as essências, fora a palmeira, o cedro é a mais importante, mesmo porque um mito de origem das árvores, atribui a criação das demais espécies ao plantio de galhos de um cedro inicial. Sua força particular provém, além dessa paternidade primitiva, na exudação da 'gota de orvalho' que sendo atributo de Jacaira/Jesuca. como a neblina e o fumo, significa que aquela madeira é uma Jesuca Venda - moradia da divindade benéfica. É claro que com essas características, tais essências vegetais representam qualidades suficientes para serem usadas na moradia tradicional - oo-e com maior razão na casa de rezas, a opy.

A casa feita com as madeiras tradicionais seria um abrigo dos deuses, assim como na antiga e intangivel tradição da guarda dos ossos descarnados dos grandes pajés que eram venerados em opy escondidos no interior das florestas, conforme relatos históricos dos séc. XVI e XVII, as caixas que os guardavam eram de cedro lavrado (H. Clastres, op. cit.; Montoya, 1985).

Hoje subsistem documentalmente. ao menos em São Paulo. os bastões de reza masculino, o altar e eventualmente o banco ritual, feitos com o cedro e outras essências sagradas. Todos eles instrumentos indispensáveis na realização de várias das mais importantes cerimônias (Costa, 1989).

Parece que o complexo cultural da busca da Terra sem Mal veicula de modo essencial o conceito guarani de desenho e arquitetura (tecoa). Nas palavras de Meliá (1990:33): "a busca da Terra sem Mal é - pelo menos no estado em que estão nossos conhecimentos - o motivo fundamental e a razão suficiente da migração guarani. E nesta se insere a especificidade da economia das tribos. A Terra sem Mal é, certamente, um elemento essencial na construção do modo de ser guarani" (teco - modo de ser guarani).

Em sua relaçāo com a espacialidade, além das características geográficas já citadas, a Busca se exprime na própria rede de estabelecimentos que guardam vínculos evidentes entre si (Ladeira e Azanha. 1988), na correspondência paisagística entre os atributos míticos e os da ecologia do tecoa - lugar onde se vive segundo o modo de ser guarani - e na correspondência das funções sócioeconômicas entre o líder do grupo em viagem e o líder do grupo estabelecido; ambos vistos como paje - pai, cantador e curador. 
Fig. 2

Migraçōes históricas guarani (apud Ladeira e Azanha, 1988).
Fig. 3

Implantação das habitações.

Desenho de Mário da Silva, guarani-mbya da aldeia. Notar: localização da praça na face leste da opy principal de José Fernandes (n. 7) e o tamanho desta construçáo. A outra opy, também importanté é a de J. Benites (n. 29). São as únicas duas construçōes associadas graficamente com árvores em toda representação.
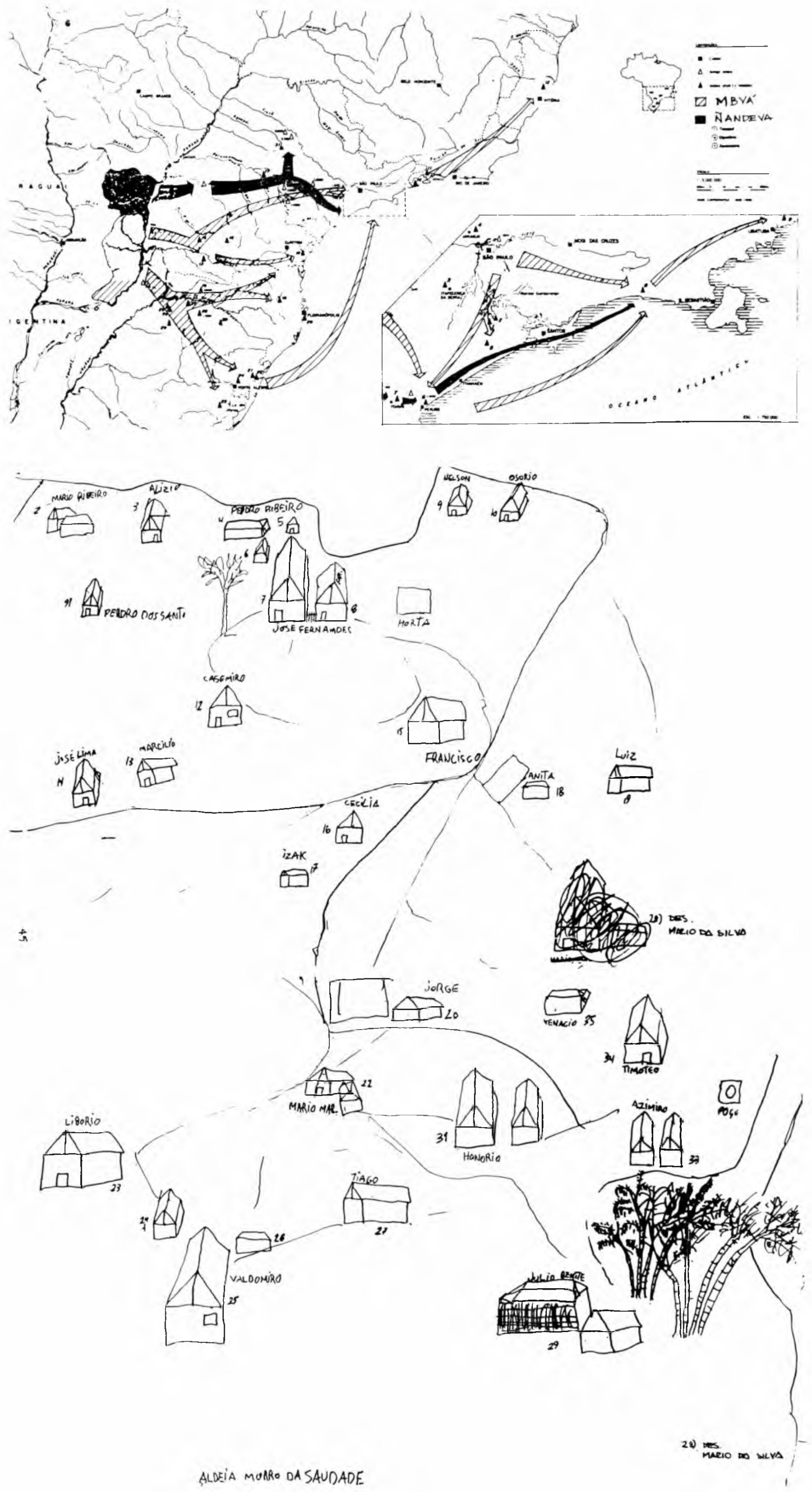
De fato é possivel verificar a continuidade da demanda guarani-mbya por novas terras onde famílias migrantes possam se estabelecer; demanda que se orienta pelo desígnio revelado por uma mulher que sonha com o tecoa e pelo desenho que a paisagem do sítio pretendido deve revelar: morros proeminentes, penhascos, serras e pedras que balizam o território, cursos d'água corrente, a eventual designação do local por étimo guarani - o que demonstra sua posse pelos ascendentes, inserçāo em vegetação florestal, altitudes de até $400 \mathrm{~m}$ e clima chuvoso.

A direçāo majoritária da migraçāo segue o rumo oriental da Terra sem Mal e é neste rumo que a rede de estabelecimentos se implantou. fazendo uma ligação clara das aldeias do interıor da floresta paraguaia até o planalto da Serra do Mar e suas encostas face ao Atlântico, passando pelo Uruguai e Argentina (Meliá, 1990; Ladeira, Azanha, 1988) (Fig. 2).

A organização social guarani é estruturada espacialmente em núcleos familiares de habitaçōes próximas que pertencem muitas vezes a um conjunto de pessoas que migraram juntos até aquele tecoa. Analogamente, a junção da coletividade da aldeia na casa de rezas - opy - denota a força da liderança religiosa na manutençāo da própria aldeia como entidade socialmente viva. $\mathrm{Na}$ verdade. o paje principal é líder de toda a aldeia. assim como o pai, que é o líder familiar, è de certa forma o paje do seu núcleo familiar, função indispensável, aliás, na liderança do grupo em mıgração.

Essa centralidade social se revela espacialmente na proeminência da casa de rezas em relação a todas as demais construções. Ela é efetıvamente o centro, não geométrico, do territorı. A centralidade fica explicitada pelo porte desta estrutura e da praça anexa. ambas sensivelmente maiores que as demais do estabelecimento (Fig. 3).

Quanto às características tecnológicas da arquitetura guarani (Costa, 1989). deve-se destacar a importância cultural de alguns materiais e da solução construtiva tradicional.

O costume do uso naval da madeira de cedro - ygary - como foi visto, permanece no banco ritual - apica - de forma muitas vezes náutica, e na construção do altar onde uma barca estilizada, que é seu travessāo, recebe a fumaça do tabaco - petin - durante os rituals religiosos. O bastão ritual masculino é o símbolo do poder e no caso do paje que è o chefe do grupo e portanto a própria encarnação do poder, nota-se correlação semântıca e funcional entre os dois: homem/objeto. De fato, o paje é o bastāo yvyrai, enquanto instrumento ritual de todo o grupo nos cumprimentos religiosos. Ele é de um certo modo, portanto, como desígnio religioso, o seu extremo, seu limite potencial enquanto ser humano. Ele é também, como desígnio ou função social, sua base e seu fundamento; ele é o bastāo, é o esteio principal e por extensão é toda estrutura da opy, sua ita.

Uma das etımologias preferidas por Cadogan para a casa de rezas é o-py, ou seja, casa central. Py denota centro, ponto fixo e também denota coração. meıo, semente. Opy seria poıs a casa central, a casa fixa, imutável e o coração da aldeia. a geradora do território guarani. Ela ocupa na arquitetura da aldeia o mesmo papel de síntese de possibilidades que o paje representa no contexto social e que o altar de cedro ocupa no espaço interno da própria opy. A opy é o coração do tecoa, assim como o paje é o coração do seu povo.

O sistema construtivo guarani baseia-se em um equilibrio estático dos esteios, cujas forquilhas apóiam os frechais e espigões que suportam o peso de toda 


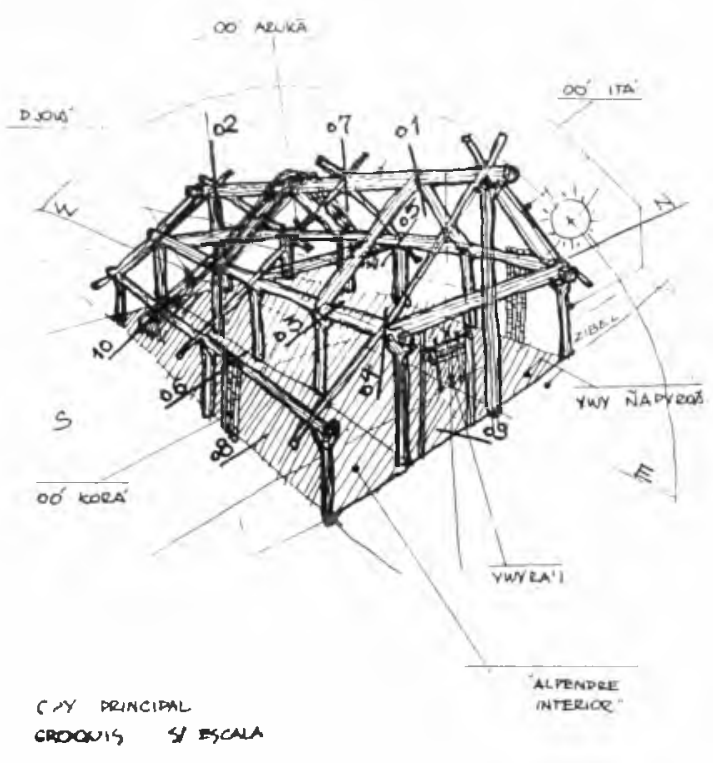

Fig. 4

Estrutura construtiva da casa guarani tradicional; solução com planta retangular. Opy de José Fernandes (sem escala).

Desenho de Carlos Zibel Costa cobertura (Figs. 4 e 5). Todas as peças descarregam o peso verticalmente e encontram-se simplesmente amarradas, assim como o conjunto da cobertura, por ilanas e cipós. Os esteios são travados por travessão em pórtico (Fig. 6). A cumieira normalmente descarrega numa forquilha cujo pontalete se apóia nos travessōes dos pórticos ou diretamente no solo de chão batido. No primeiro caso obtém-se um espaço interno livre, graças ao funcionamento da tesoura guarani ou cabocla (formada por um único esteio central, sem os braços inclinados); no segundo caso existe no eixo do vão central um ou mais esteios. A casa de rezas principal da Barragem observada entre 1985 e 1989 oferecia exemplo particular e engenhoso de suporte da cumieira. Ela era sustentada somente pelos caibros das duas águas sem qualquer esteio central, abrindo vão admirável para aquela técnica construtiva (Foto 3 ).

Usa-se sempre que possivel folhas da palmeira - pindoba - na cobertura; em sua falta, usa-se o sapé - jape. Entre as palmeiras, as melhores folhas são as do palmito - jejy - e as da jaricanga, pindo guaçu e ai'i. Elas são amarradas em sarrafos de galhos de árvore, varas de bambu ou pequenos troncos de palmeira. Hoje está difundida nas construçōes comuns, fora da casa de rezas, a utilização de arames e pregos, além de dobradiças metálicas nas portas e janelas. Como contraponto a esse desenho guarani, pode-se lembrar que na tese foram estudadas outras construçōes tupi-guarani como as casas tradicionais do grupo Asurini do Xingú. A principal diferença deste com o sistema construtivo guarani é a utilização de varas tensionadas - jarokinga - na função de caibros. Essa soluçāo confere às construçōes tradicionais asurini, tetos em abóboda ogival. A outra diferença é que enquanto a planta guarani admite um dos lados curvos, o asurini pode ter os dois lados encurvadns. Naquela oportunidade verificou-se profunda correspondência entre a casa ritual, a figura

Fig. 5

Levantamento de casa guarani tradicional de planta ortocircular. Opy de J. Benites (sem escala).

Desenho de Rui Alāo.

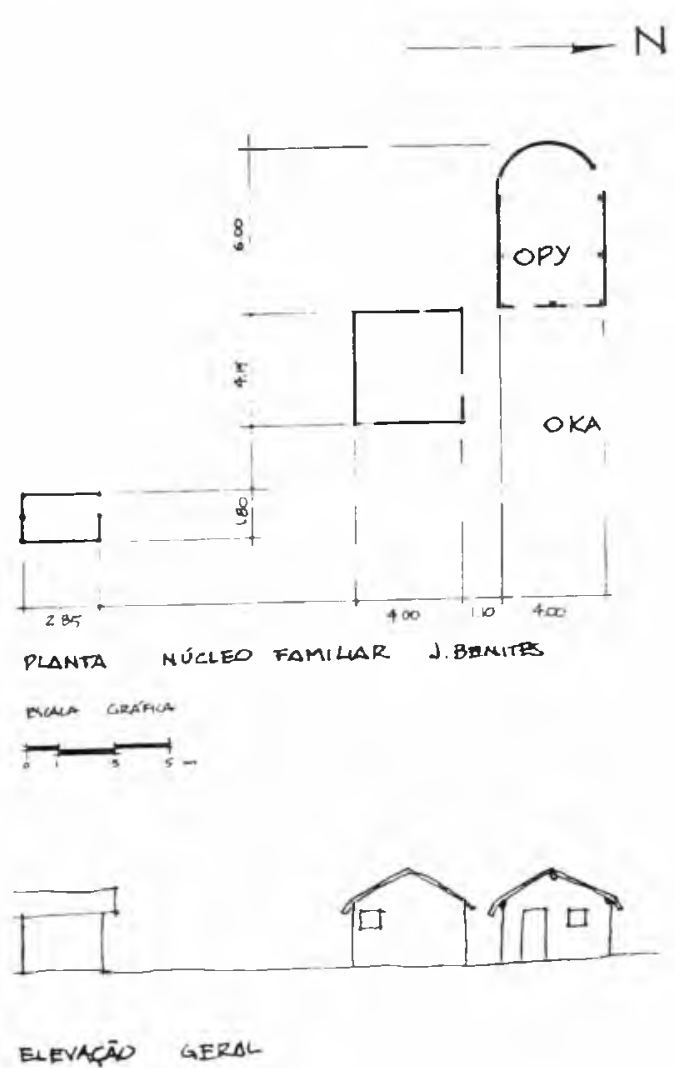

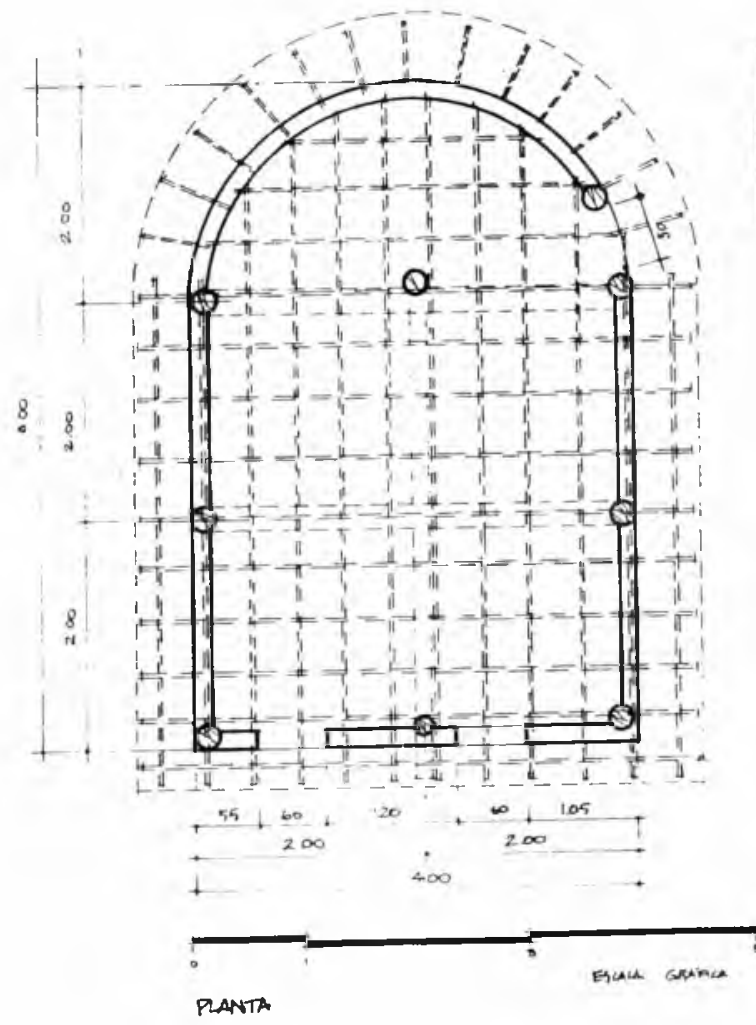

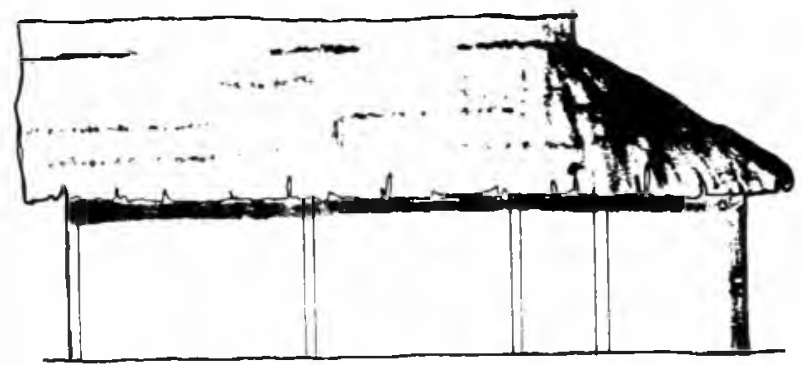

FACHADA NORTE

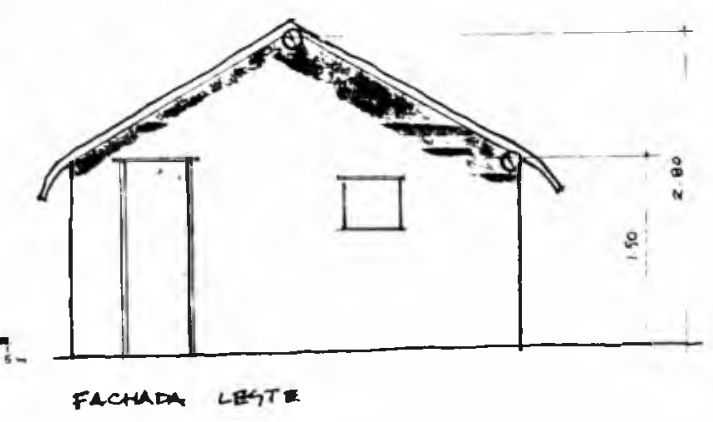


Fig. 6

Detalhes construtivos tradicionais (det. 01 a 10). Os números correspondem à marcação no croquis da Fig. 4 (sem escala).

Desenho de Carlos Zibel Costa
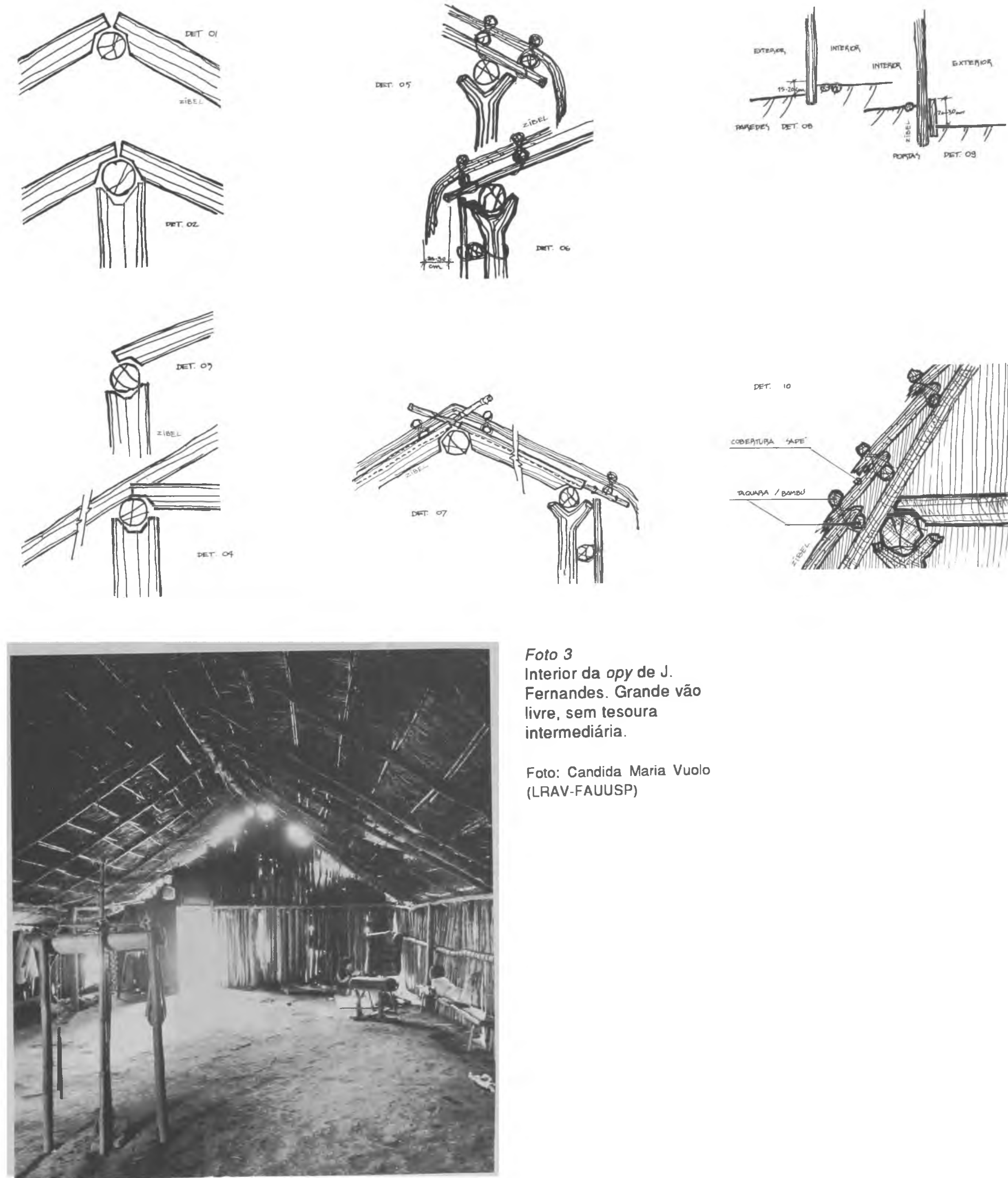

Foto 3

Interior da opy de J.

Fernandes. Grande vão

intermediária.

Foto: Candida Maria Vuolo (LRAV-FAUUSP) livre, sem tesoura

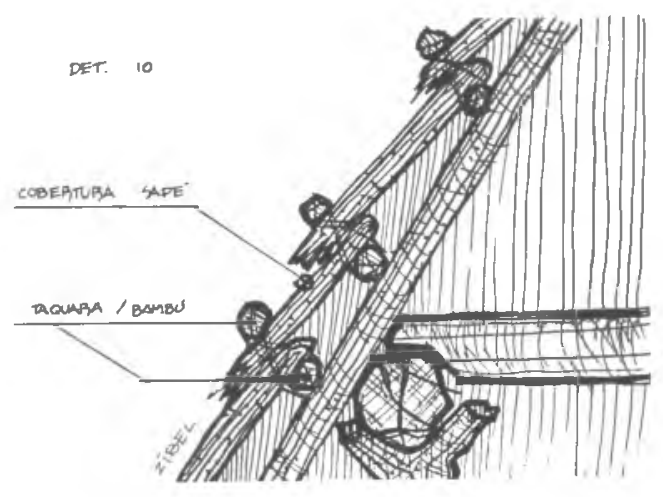




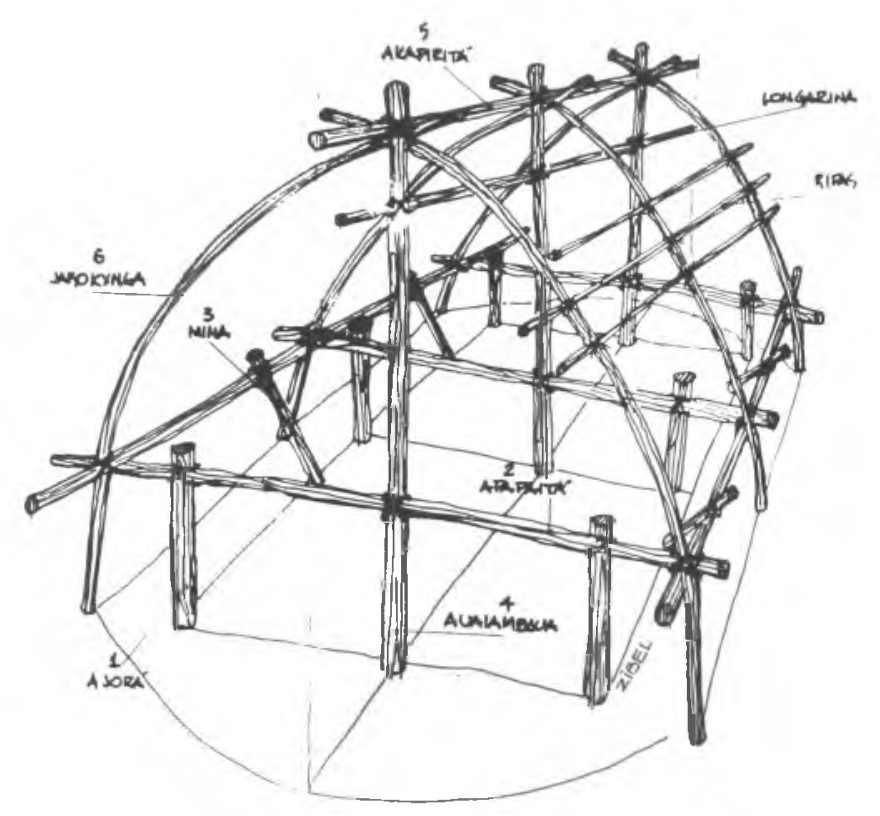

Fig. 7

Estrufura construtiva da casa tradicional - aketedo grupo tupi-asurini do Xingú (sem escala).

Desenho de Carlos Zibel Costa

Foto 4

Vedaçāo em pau-a-pique, cobertura em sapé.

Foto: Candida Maria Vuolo (LRAV-FAUUSP)

Foto 5

Vedação em taipa de mão

Foto: Candida Maria Vuolo (LRAV-FAUUSP)
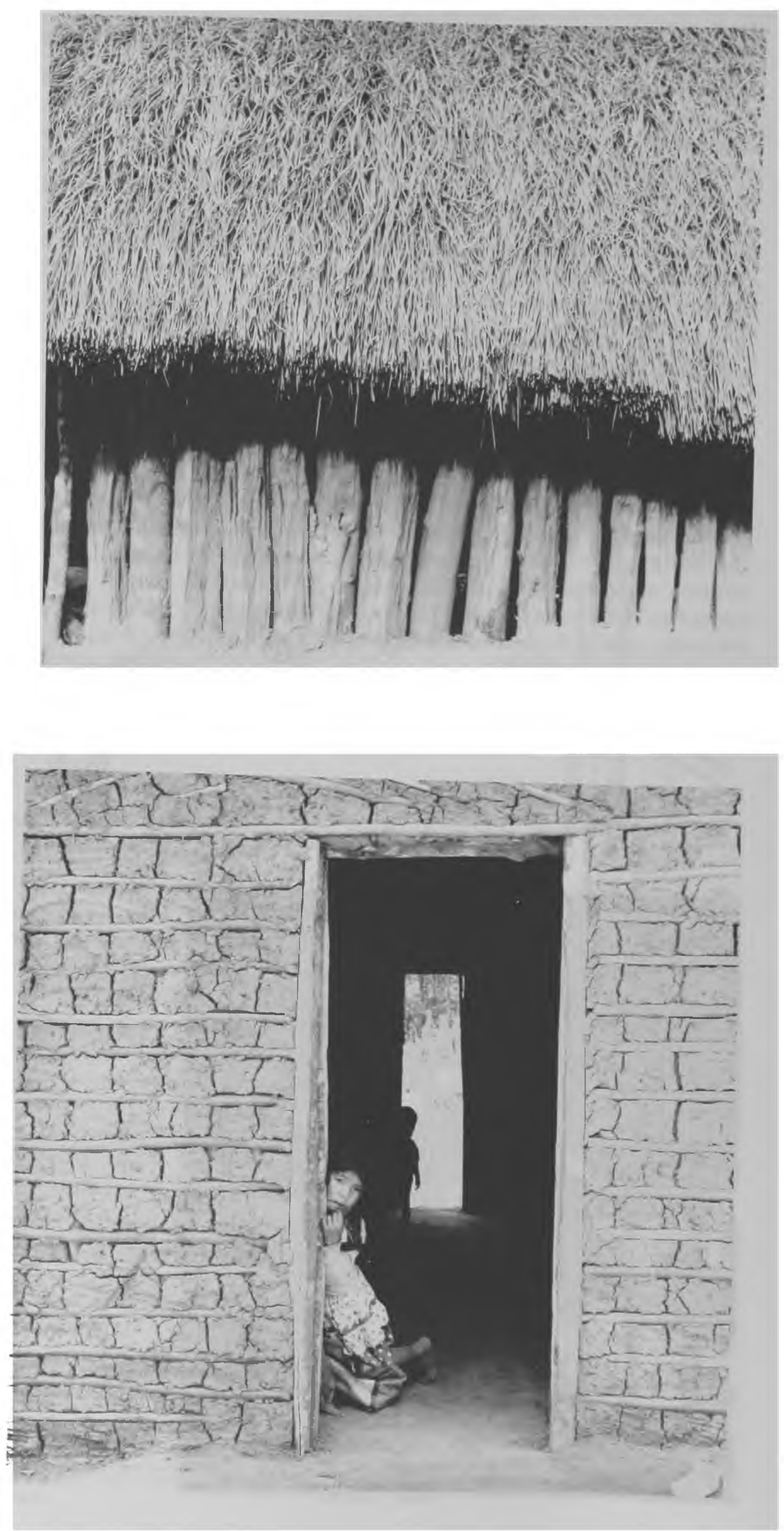

Pós - R. Prog. Pós-Grad. Arquit. Urb. FAUUSP, Sáo Paulo n.4 p. 113-130 dez. 1993 
humana arquetípica, que entre os tupi-guarani conforme demonstra Florestan Fernandes (1948), é sempre o pajé. e a organização social tupi-asurini baseada no marido com suas duas mulheres (Fig. 7).

Retomando o caso guarani, foi verificado na construçāo de opy com pilar central para suporte da cumieira, ocorrência de ritos religiosos entre os guarani-nhandeva onde se identifica o conjunto cruciforme do pilar e travessāo central com o altar. Tal fato relatado por Schaden (1974) sugere a transformação da própria Arquitetura em objeto ritualístico e instrumento relıgıoso conforme lembrado no início do texto ao se estudar a correspondência da opy com a pindovy no mito do casal incestuoso.

Nas casas comuns, a vedaçāo predominante é bastante leve, feita em pau-apique - estaquedo vertical de pequenos troncos amarrados entre si e a longarinas horizontais que os vinculam à estrutura (Foto 4). A vedação de pau-a-pique, embora crie um filtro visual suficiente para ocultar em sua penumbra o interior da habitação, revela ao seu habitante todo o exterior, mais iluminado. Além disso, ela parece, pela sua fragilidade, funcionar mais como pele e marco do que divisāo interior-exterior. Tal característica de troca constante entre os dois ambientes, garante alto nivel informacional que, entre os guaranis, verificou-se passar pelos sons e cheiros trazidos pelo vento. além da informaçāo visual que atualmente predomına em nossa sociedade.

Em algumas situaçōes pode-se notar um incremento na estanqueidade das vedaçōes por meio do uso tradicional do barro - como taipa de mão (Foto 5), ou do revestimento com folhas de palmeira e mesmo do uso de materiais improvisados e nāo consagrados, como tecidos, plásticos, telhas de fibrocimento e madeiras processadas industrialmente.

Seria preciso um estudo mais profundo para verificar se o aumento da estanqueidade corresponde simplesmente à demanda ocasionada por conforto técnico e acústico, como geralmente pretendem as etnografias, ou existe aí também um componente ideológico guarani.

Alguns pesquisadores têm anotado recomendações sobre o fechamento da casa de rezas. Em pesquisa na aldeia da Barragem foi recolhida uma explicação sobre a conveniência da estanqueidade da casa de rezas baseada no preceito de se evitar a circulação de vento que poderia prejudicar as rezas em andamento. Infelizmente nāo foi possivel dar continuidade a essa investigaçāo. porém tudo indica que esses preceitos devam efetivamente existir; é o que se depreende por exemplo do material gráfico, do excelente levantamento feito por Perasso e Vera (s/d: 100, 108 e 139) entre os nhandeva do Paraguai, onde o fechamento meticuloso das faces sul da opy contrasta fortemente com a leveza ou inexistência de vedaçāo nas paredes orientais.

É certo que existe a postura tradicional face leste que orienta ritualmente os guarani e as suas habitações, especialmente as casas de rezas e pátios, suficientemente documentado na etnografia. Porém a questão do grau de estanqueidade das vedaçōes poderia ter relaçāo com o conceito dos Pais da Palavra, segundo se depreende dos estudos de Cadogan (1959) e Inês Ladeira (1992), particularmente com a Origem dos Ventos Primeiros e a divindade Carai.

Finalmente deve-se abordar aquela que é talvez a dimensão menos divulgada da Arquitetura, o tempo, que representa entretanto papel essencial no conceito de espaço. Entre os guarani a influência do tempo pode ser percebida na economia de caráter essencialmente agrícola que se organiza, até socialmente. em funçāo das atividades de cultivo; do milho em particular. 
Pode-se verificar nas Fotos 6 e 7 como a aldeia da Barragem muda sua imagem de acordo com o estágio das roças de milho. Lembre-se que a cada estágio desse plantio deve corresponder na sociedade indígena uma série de ritos e preparações que irão culminar à época da colheita com a realização da cerimônia do batismo do milho, nhemongaral e a atribuiçāo do nome tradicional, dado pelo paje, às crianças pequenas (Ruiz, 1984).

À semelhança da qualificação paisagística que o cultivo do milho fornece ao espaço, também o tempo deste cultivo qualifica o espaço, ou melhor, o tempo desenha intenções diversas no espaço guarani. Inês Ladeira (1992) constata por exemplo que o período mínimo de permanência num tecoa é de quatro luas, duração do ciclo completo do plantio do milho. Quatro luas é então o tempo mínimo necessário à formação do tecoa tradicional ou sua recuperação ecológica. É claro que esse será também o ritmo das migraçōes e que, em função disso se dará o passo da migração. Como existem épocas apropriadas para o plantio e a colheita do milho e também ao corte das árvores e sapé para a construção, constata-se o forte compromisso temporal da Arquitetura e do território guarani que condiciona, entre outras coisas, a duração e os passos da

\section{Foto 6}

Vista do norte. Presença da palmeira - pindo, casa de rezas - opy - e praça principal - oca. Notar roças de milho ainda não plantadas.

Foto: Carlos Zibel Costa

\section{Foto 7}

Vista do nordeste; oca e opy principal. Notar alteração espacial devido ao crescimento do milho.

Foto: Evandro Carlos

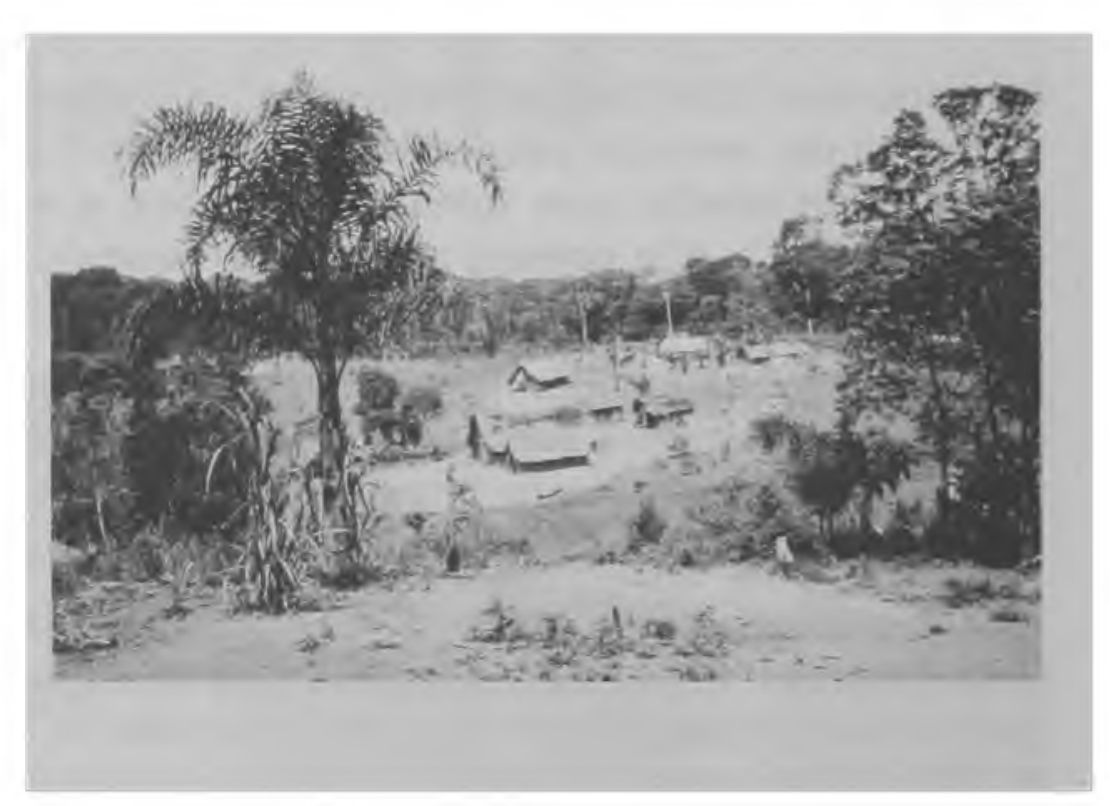


migraçāo. O passo condiciona os sítios que podem ser atingidos naquela viagem, enquanto o ritmo condiciona, entre outras variáveis, a duração das construçōes, seu acabamento e a escolha dos materiais. As interpretaçōes que buscam explicar o fenômeno das migraçōes pela motivação puramente econômica procuram ignorar a forte ligação observada entre os ciclos agrícolas, especialmente do milho e do chá, e os vários ritos do complexo cultural da Busca da Terra sem Mal.

\section{Observações Finais}

Como reflexo direto da situação de trânsito ou de curta permanência, a arquitetura guarani apresenta soluçōes estruturais onde destacam-se os simples encaixes em forquilha ou no máximo algum rebaixo simples para facilitar a justaposição e a amarração, sendo raríssimos os casos de entalhes ou encaixes complexos (Foto 8). Apresenta, entretanto, acabamentos criativos e de grande funcionalidade, como o uso de esteiras de folhas ou trançados de cipó ou taquara, além de vedos em pau-a-pique, muito bem feitos (Foto 9). Não se verifica amiúde acabamentos em argila, tijolo ou pedra, embora como foi dito acima, haja pleno conhecimento de técnicas complexas, como a taipa de sopapo.

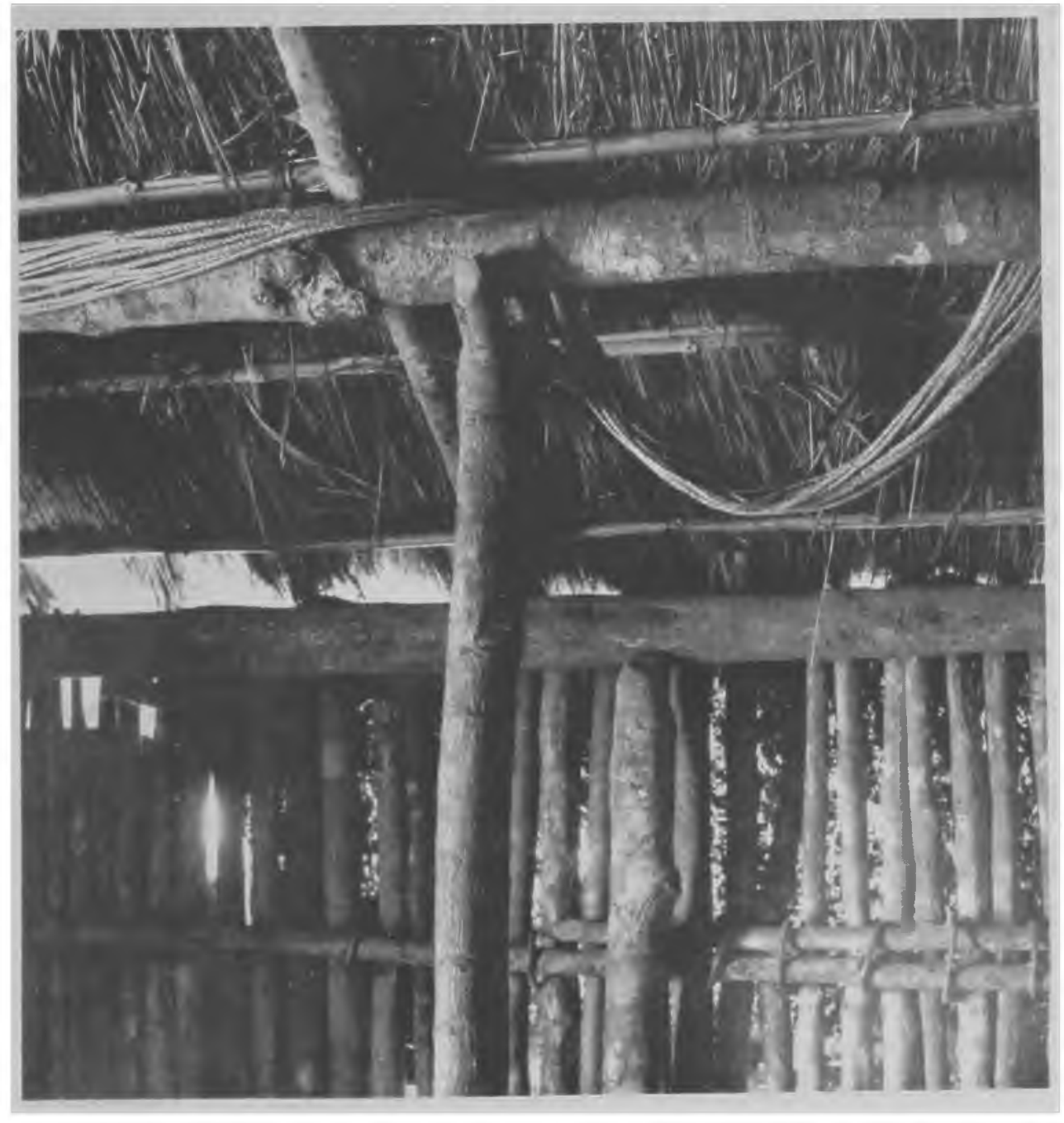

Foto 8

Encaixes e amarrações, parede - oo cora - de pau a pique, cobertura joia - de sapé, amarraçāo de cipó - guaimbe.

Foto: Candida Maria Vuolo (LRAV-FAUUSP)

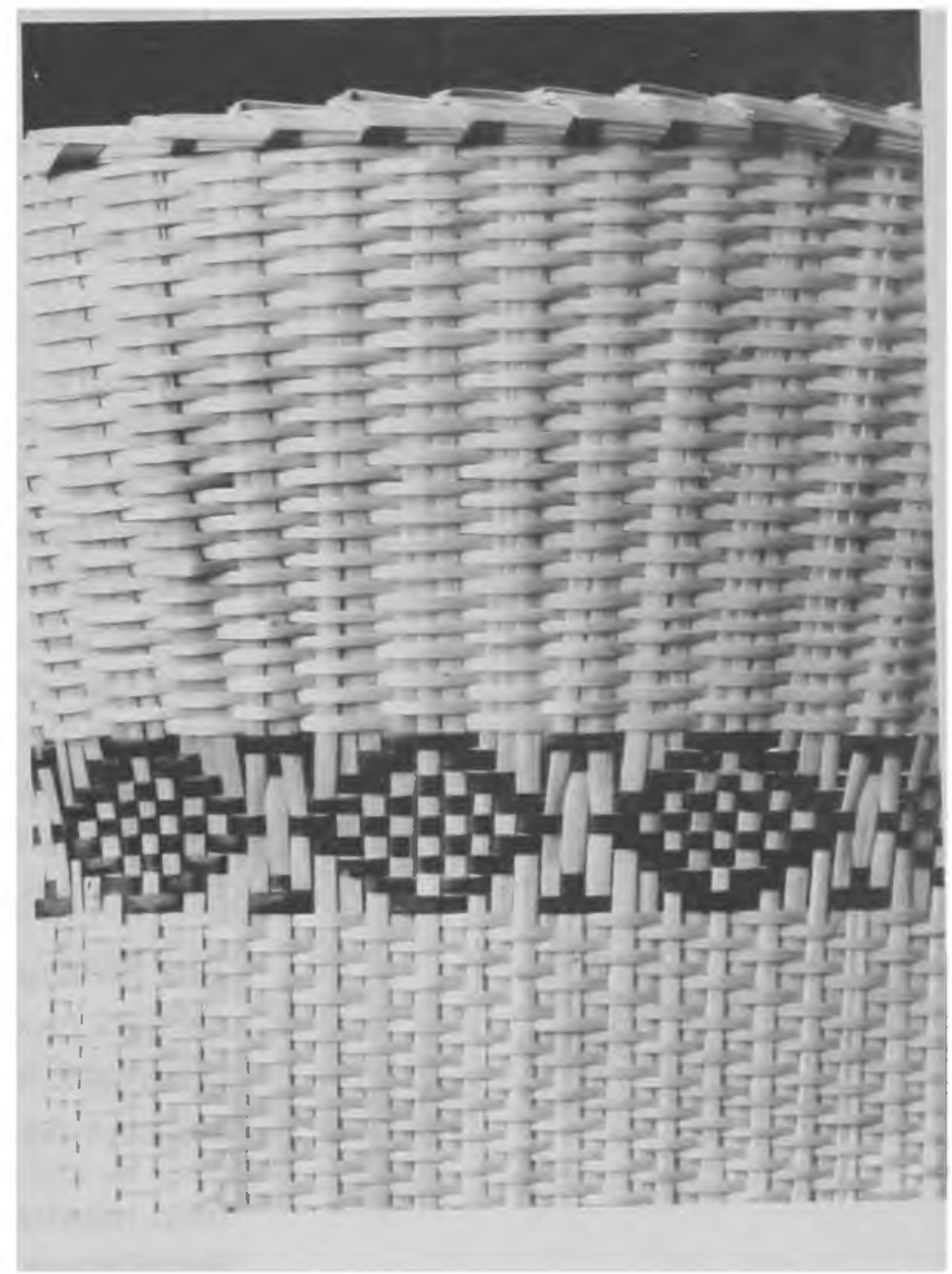

Foto 9

Cestaria tradicional - ajaca - de grande qualidade; trançado com lascas de taquara e casca de cipó preto.

Foto: Roberto Bogo (LRAV-FAUUSP) 
A aparência simples ou rústica que eventualmente suas construçōes e as aldeias aparentam deve-se em boa parte à situação de mudança que a cultura Ihes proporciona, a supremacia da motivaçāo espiritual sobre as demais na sociedade guarani e à decadência da condição ecológica que o cerco da sociedade branca acarreta no seu território

Alguns autores advogam que a Busca da Terra sem Mal não e prerrogativa exclusiva dos grupos guarani e que os demais grupos da civilização tupi-guarani dela compartilhavam. Parece, entretanto, segundo $\mathrm{H}$. Clastres, que à época da descoberta da América, especialmente os grupos tupi conheceram acentuada sedentarização. Os textos da época falam em milhares de habitantes por aldeias e que elas se coordenavam por uma espécie de chefe militar regional. A autora defende a idéia de uma incipiente urbanizaçāo daquela civilização, algo como a pré-história de um império oriental americano que se anteporia ao império inca ocidental.

O fato é que não se pode nem se deve descartar a possibilidade de sedentarizaçāo da aldeia guarani, já que em sua cultura houve oportunidades em que suas aldeias cresceram como todas as do resto da família tupi-guarani e é muito provável que. nessa circunstância, a sua Arquitetura tivesse se transtormado em estruturas mais acabadas e maiores.

Como filho legítimo da civilização indígena, vale dizer tupi-guarani, a arquitetura cabocla brasileira como a dos caipiras - caa porã - e caiçaras - caa sara mantém até hoje, de modo explícito, enorme rol de influências culturais daquela civilização (Antonio Candido, 1987).

$\mathrm{Na}$ arquitetura cabocla, por exemplo, é mais correto falar do que nāo the corresponde de fonte indígena, e logo lhe corresponderá de fonte européia, do que listar uma enormidade de caracteristicas indígenas.

A influência tecnológica européia só aparece com força nos exemplos mais aprimorados de construção: casas de família com mais posses. sedes de grandes fazendas e equipamentos oriundos da cultura europeia como os moinhos de cana-de-açúcar. Tais construçōes se caracterizam pelo uso de soluçōes decorativas dos beirais, encaixes complexos na carpintaria, pisos de pedra ou cerâmica, uso de esquadrias e revestimento fino nas paredes de barro. Os demais equipamentos e construçōes, porém, mostram claramente sua raiz indígena. Observando-se na cultura cabocla construçōes transitórias como pousadas de caça e coleta no sertāo, ou abrigos de pescadores e seus barcos nas praias, verifica-se que na maioria das vezes aquilo que era semeIhança passa a ser identidade, tamanha é a correspondência entre estas soluções e as Indígenas.

Em verificação recente constatou-se que no estado de São Paulo, de um total de 625 municípios, 218 têm nome inteiramente tupi-guarani, o que equivale a dizer que ainda hoje, cinco séculos após a colonização portuguesa, 35\% das cidades paulistas mantêm denominação indígena.

Isso mostra que nos assuntos ligados à terra, assim como aqueles ligados à Arquitetura e equipamentos que acabamos de expor, e mesmo às lides da Ecologia como a agricultura, caça, pesca, recolha de ervas, frutas e madeiras conforme demonstram trabalhos de Sérgio Buarque de Holanda e a moderna etnografia, o Brasil deve muitíssimo à civilização tupi-guarani. Embora cada vez mais seja dificil e raro que sobrevivam a Arquitetura. os equipamentos e 
mesmo o modo de vida caboclo, é certo que as marcas dessa influência permanecerāo vivas em nossa cultura material, quanto mais ainda no espírito brasileiro onde a raça, as expressōes e a indole indigena adquiriram estatuto nacional.

\section{Bibliografia}

CADOGAN, Leon. "Ayvu Rapyta, textos míticos de los Mbyá Guarani del Guairá" Sāo Paulo, Boletim 227. Revista de Antropologia, n. 5, FFLCH-USP, 1959.

CADOGAN, Leon. "La encarnación y la concepción; la muerte y la resurrección en la poesia sagrada 'esotérica' de los Jeguaká-va Tenondé Porä-Güé (Mbyá-Guarani) del Guairá, Paraguay" Sep. da Revista do Museu Paulista. Sāo Paulo. Nova Série, v. IV, 1950.

. YWYRA NE'ERY. flue del arbol la palabra. Asunción: Centro de Estudios Antropologicos, 1971.

CANDIDO. Antonio. Os parceiros do Rio Bonito - estudo sobre o caipira paulista e a transformaçāo dos seus meios de vida. São Paulo: Duas Cidades. 1987

CLASTRES, Hélène. Terra sem Mal - o profetismo tupi-guarani. São Paulo: Brasiliense, 1978.

COSTA, Carlos Zibel. Habitação Guarani - tradição construtiva e mitologia. Sāo Paulo, 1989. Tese (Doutorado) - Faculdade de Arquitetura e Urbanismo, Universidade de São Paulo.

FOSTER, George M. As culturas tradicionais e o impacto da tecnologia. Rio de Janeiro: Fundo de Cultura, 1962.

FERNANDES. Florestan. A organização social dos tupinambás. São Paulo: Progresso Editorial, s/d.

HOLANDA, Sérgio Buarque de. Caminhos e fronteiras. Rio de Janeiro: José Olímpio, 1957

LADEIRA, Maria Inês. O caminhar sob a luz - o territorıo mbyá à beira do oceano. Sāo Paulo, 1992. Dissertaçảo (Mestrado) - PUC.

LADEIRA, Maria Inês e AZANHA, Gilberto. Os indios da Serra do Mar. Sāo Paulo: Nova Stella, 1988.

LADEIRA, Maria Inês, COSTA, Carlos Zibel. A geografia mítica guarani-mbyá. Comunicaçāo oral. In: SEMINÁRIO INTERNACIONAL "O NOVO MAPA DO MUNDO" Sāo Paulo, FFLCH-GEO-USP 1992.

MELIÁ, Bartomeu. "A Terra sem Mal dos guaranı - Economia e Profecia". In: Revista de Antropologia. v. 33. São Paulo. FFLCH-USP. p. 33-46. 1990.

El guaranı conquistado y reducido. Ensayos de etnohistoria. Assunción. Biblioteca Paraguaya de Antropologia, v. 5, 1988.

MELIȦ, Bartomeu; GRÜNBERG, George; GRÜNBERG, Friedl. "Los Pāi Tavyterā: Etnografia Guarani del Paraguay Contemporaneo" Assunción. Suplemento Antropologico, 1976. XI, 1-2: p. 151-295.

MONTOYA, Pe. A. Ruiz. Conquista espiritual. Porto Alegre: Martins Livreiro Editor, 1985.

NIMUENDAJU், Curt. As lendas da criação e destruição do mundo como fundamento da religiāo dos Apapocuva-Guarani. São Paulo: Hucitec-Edusp, 1987

PERASSO, José A.; VERA. Jorge. La cultura guarani del Paraguay contemporaneo (etnografia Ava-Kue-Chiripá). Assunción: RP Ediciones. s/d.

RUIZ. Irma. "La ceremonia 'ñemongarai' de los 'Mbyá' de ia Provincia de Misiones" In: Temas de Etnomusicologia - 1. Buenos Aires. Min. de Ed. y Justicia / Secretaria de Cultura, 1984. 
SCATAMACChIA, M. C. M., MOSCOSO, F "Análise do Padrāo de Estabelecimentos Tupi-Guarani" In: Revista de Antropologia, vs. 30, 31, 32, 1987. 1988 e 1989. São Paulo, FFLCH-USP, 1989, p. 37-53.

SCHADEN, Egon. Aspectos fundamentais da cultura guarani. $3^{a}$ ed., Sāo Paulo: E.P.U./Edusp, 1974.

OBS: Fora Figs 1, 2 e 7, todas as demais ilustraçōes referem-se à aldeia guarani-mbyá Morro da Saudade (Barragem) em Parelheıros, Sảo Paulo, entre 1985-1988 